\title{
Exploring How Referral Reward Program Design Affects Consumer Intent to Purchase from a Recipient Perspective
}

\author{
Chia-Lee Fan ${ }^{1}$, Yi-Liang $\mathrm{Su}^{2}$, Sue-Ting Chang ${ }^{3} \&$ Day-Yang Liu ${ }^{1}$ \\ ${ }^{1}$ Graduate Institute of Finance, National Taiwan University of Science \& Technology, Taipei, Taiwan \\ ${ }^{2}$ Yuanta Bank, Taipei, Taiwan \\ ${ }^{3}$ Commerce Development Research Institute, Taipei, Taiwan \\ Correspondence: Chia-Lee Fan, Graduate Institute of Finance, National Taiwan University of Science \& \\ Technology, Taipei, Taiwan. Tel: 886-917-766-285. E-mail: chialeefan@must.edu.tw
}

Received: August 1, 2014

Accepted: September 19, 2014

Online Published: October 22, 2014

doi:10.5539/ijbm.v9n11p21

URL: http://dx.doi.org/10.5539/ijbm.v9n11p21

\begin{abstract}
The purpose of this study is to examine how enterprises use referral reward programs to acquire new customers effectively. We adopt two experimental designs and establish four hypotheses based on how referral reward subject category and reward type affect the likelihood of customer response. The results show that low-involvement products should reward recipients or offer financial rewards to increase intent to purchase. Customers perceive fairness of distributive justice as the underlying mechanism for the influence that reward recipient category and product involvement have on intent to purchase. Finally, implications and limitations for future research are discussed.
\end{abstract}

Keywords: involvement, perceived fairness, purchase intention, referral reward programs, word-of-mouth

\section{Introduction}

Word of mouth (WOM) is a critical factor that affects purchasing decisions. In recent years, numerous enterprises have used WOM to promote consumption. Referral reward programs (RRPs) are a channel for such promotions. RRPs have a significant positive influence on enterprise profits (Kumar, Petersen, \& Leone, 2010). Schmitt, Skiera and Bulte (2011) demonstrate that a referred customer provides $16 \%$ more value to an enterprise compared to non-referred customers. Google search from 2014 for the keywords "referral reward program" generates 60 million hits. In most scenarios, the enterprise offers rewards to current customers for referring other people, and these people may also receive rewards as new customers. The following are examples of RRPs from a variety of industries:

- Recommending credit card to a friend earns both the referrer and recipient bonus rewards.

- Earn a referral reward in the form of a voucher for a seasonal gift for each referred friend who signs up for a direct debit gym membership.

- Get a \$100 NTD discount on future tours for each referred friend. The friend also receives a \$100 NTD discount on the original tour.

Previous studies have primarily focused on exploring the effectiveness of RRPs by providing referrer incentives (Witz \& Chew, 2003; Ryu \& Feick, 2007; Garnefeld, Helm, \& Tax, 2013). Although several recent studies focus on the perspective of recipients, these studies assume that recipients don't know that referrers are rewarded by enterprises for their referrals (Ahrens, Coyle, \& Strahilevitz, 2013; Jin \& Huang, 2014). In reality, recipients may well be aware that referrers receive rewards for referring others. Relevant literature indicates that if recipients know that people are referring them to obtain a reward, they perceive that the referrer has an ulterior motives (Verlegh, Ryu, Tuk, \& Feick, 2013). Accordingly, the likelihood of a recipient accepting a referral is reduced.

In contrast, this study focuses on the perspective of the recipient. The first study objective is to increase the likelihood of referral acceptance using various reward designs in which recipients are aware that referrers are rewarded. The second study objective focuses on design programs in which the reward target is either a recipient or both a recipient and a referrers; the influence of various reward designs are then explored. Finally, the third study objective is to examine how product involvement affects the influence of perceived fairness of distributive 
justice on RRPs. As persuading the recipient is the key to a successful transaction, it is reasonable to hypothesize that the recipient's perception of justice throughout the entire transaction plays a vital role in terms of predicting the likelihood of purchase (Ahrens et al., 2013).

This study incorporates the following framework: (a) a literature review of extant studies on referral rewards and purchase intentions is performed, and research hypotheses are subsequently developed; (b) relevant experiments are conducted to analyze reward subject category in Study 1 and reward type in Study 2; and (c) a general discussion of the results and implications for management are provided.

\section{Literature Review}

\subsection{Research on Referral Reward Program}

Increasing WOM referrals is regarded as a critical marketing objective as it effectively gains new customers, establishes long-term relationships, and increase customer value. RRPs primarily prompt existing customers to produce WOM referrals by providing rewards, thereby persuading new customers through recommendations or referrals to purchase enterprise products or services (Ryu \& Feick, 2007). Compared to traditional marketing methods, relationships with new customers gained through WOM referrals tend to last longer (Trusov, Bucklin, $\&$ Pauwels, 2009). For new customers acquired through other means, the average value of a referred customer is significantly higher than for a non-referred customer in a similar demographic (Schmitt et al., 2011).

Prior studies related to RRPs have examined three different aspects of this topic. The first aspect includes examining which factors influence the possibility of referrals from existing customers or the occurrence of WOM referrals from a referrer perspective (Ryu \& Feick, 2007). The second aspect investigates the value produced by RRPs for enterprises from an enterprise perspective. The customer value generated for the enterprise by new customers gained through RRPs tends to be higher than the value produced by non-RRP customers (Kumar et al., 2010; Schmitt et al., 2011). The third aspect relates to examining the positive, neutral, or negative responses of new customers following WOM referrals from a recipient perspective (Verlegh et al., 2013).

\subsection{Subject of Reward Allocation and Perceived Fairness}

RRPs most frequently reward three categories of people. The first category is a reward to the referrer. Ryu and Feick (2007) assert that, in the context of weak ties, a reward provided to the referrer is more likely to produce more referrals compared to a reward provided to the recipient. Ahrens et al. (2013) also suggest that providing higher referrer rewards attracts more new members or purchasers and that providing additional rewards to recipients does not increase recipient referrals. The second category is a reward to the recipient. Xiao, Tang and Wirta (2011) study RRP design and conclude that providing more rewards to recipients than to referrers produces optimal results. Ryu and Feick (2007) show that with strong ties, consumers are most likely to provide referrals in a reward-recipient condition. The third category provides rewards to both the referrer and the recipient (i.e., new customers). Wirtz, Orsingher, Chew, and Thambyah (2013) suggest that if both the referrer and recipient receive an incentive, the metaperception of the referral might be less negative. Verlegh et al. (2013) indicate that compared to rewarding only the referrer, a "reward both" reward allocation scheme is less likely to reduce the favorability of referral responses.

\subsection{Equity Theory}

Studies have demonstrated that WOM referral for recipients that perceive fairness is the critical factor in deciding whether or not to adopt an RRP (Ahrens et al., 2013; Choi \& Kim, 2013) because the role of WOM referral is to spread awareness and provide assessments. We adopt an equity theory that may explain the decision-making process used by the two parties. The relational satisfaction of groups regarding the fair distribution of resources during social exchanges is a core topic in the study of equity theory. Customers care about whether the ratio between cost and benefit is reasonable or not a concern that is also known as perceived fairness.

The aforementioned studies have reported that the perceived fairness of an RRP differs according to whether a person is a referrer or recipient. The possibility of a referral reward being accepted is low if the recipient perceives that the referrer is "selling" through WOM to acquire specific benefits (Ryu \& Feick, 2007; Tuk, Verlegh, Smidts, \& Wigboldus, 2009). Because enterprises may use referral rewards to exploit the social exchange relationships between existing and new customers, customers consider and are concerned about the input to outcome ratio involved in the exchange (Oliver \& Swan, 1989). From the perspective of the recipient, if they are rewarded after they accept a referral program, they may consider these rewards as compensation for assisting the referrers in achieving the compensation generated by their performance goals (e.g., costs). 
Accordingly, recipients might be more likely to accept the referral program. Therefore, we argue that if recipients perceive that they or both parties can be rewarded, the possibility that they accept a referral program is higher than that of recipients who perceive that the referral benefits only the referrers.

\subsection{Product Involvement and Perceived Fairness of Reward Subject in RRPS}

Product involvement has been found to significantly moderate the relationship between referral consistency and the perceived credibility of the persuasive effect (Cheung, Luo, Sia, \& Chen, 2009; Lee, Park, \& Han, 2008). In previous consumer studies, product involvement has been viewed as a marketing incentive having a strong influence on customer perceptions and behavioral responses (Laaksonen, 1994). High-involvement products are typically complex in function or content; common examples include smart phones, training courses, and tourism. With this type of product, consumers are generally expected to search for additional information and allocate greater amounts of time when considering optimal purchase decisions prior to a high-involvement purchase (Celsi \& Olson, 1988). Low-involvement products typically possess single functions or simple content (e.g., books, CDs, or consumer goods). Customers do not actively search for or attempt to understand relevant product knowledge.

In this study, we propose that when customers receive referrals for high-involvement products, the referral recipients might not be concerned with whether rewards are awarded to the referrers or recipients because of their long-term interest in the product. By contrast, when customers are provided information on low-involvement products with which they are not highly concerned, they naturally prefer rewards that benefit themselves the most, followed by rewards for both parties, and finally, by rewards for the referrers (and no rewards for themselves). Besides this, we examine how enterprises design RRPs to encourage recipients to purchase products or services in this study; therefore, intent to purchase is considered to be the effect of consumers being persuaded to accept referral messages. Thus, following hypothesis is proposed:

$\mathrm{H}_{1}$ : The influence of a RRP design on recipient response depends on product involvement. Under low involvement, the purchase intention regarding a RRP is higher for the reward recipient, followed by reward both and reward referrer. Under high involvement, there is no difference in the purchase intention regarding a RRP for reward recipient and reward referrer.

In previous studies, consumer perceived fairness is categorized as distributive justice, procedural justice, and interactional justice (often conceptualized as the fairness of distributive justice, e.g., Bowman \& Narayandas, 2001; Palmer, Beggs, \& Keown-McMullan, 2000). Because this study is focused on exploring the recipients' perceived fairness regarding outcomes before purchase, procedural justice, which occurs during the process of referrals, is not included; we primarily examine issues regarding perceived distributive justice. Distributive justice primarily involves the perceived fairness of resource allocation and outcome distribution, whereas procedural and interactional justice represents the perceived fairness of the process used to deliver the outcome, referred to in shorthand as perceived fairness hereafter.

We propose that the concept of fairness will be an important mediator in providing prior literature about the social exchange processing of perceived justice between input and outcome. The recipients perceive the rank of fairness according to the various persons that will be rewarded. RRPs that reward recipients may produce the strongest sense of distributive justice. Therefore, perceived fairness can be a critical cause for determining whether or not a referral should be accepted. We subsequently propose the following hypothesis:

$\mathrm{H}_{2}$ : Fairness of distributive justice will mediate the moderation effect of involvement level on the effect of reward subjects on purchase intentions.

\section{Study 1: Reward Subjects of RRPs}

The purpose of Study 1 is to explore who the person that will be rewarded is and determine which factors influence recipient response. The intent to purchase for the recipient is investigated to examine the moderating effects of product involvement. Moreover, we hypothesize that the recipients' perceived fairness is a mediating factor that influences their intent to purchase.

\subsection{Participants, Study Design, and Procedures}

Using between-subject experimental design, the participants are randomly assigned to one of six categories according to three categories of reward subject, referrer, recipient, and reward both, and two kinds of product involvement, high and low. Most of the 195 college student participants recruited for the study are from a college in central Taiwan. Each study participant receives extra credit as compensation. The average age of the participants is 21.32 years; $60.0 \%$ are female. 
At the outset of the experiment, participants are informed that they are taking park in a marketing research study that examines consumer response. Participants are then told that they will read a short scenario of a marketing plan in a manual. Subsequently, the participants are informed that they will be exposed to messages related to the plan. Their reactions in the relevant scenario are then evaluated.

The participants are asked to envisage that they need to purchase a certain product. In this study, tourism and desks are selected for the following reasons: (a) Tourism has been classified as a high-involvement product by previous studies (Dholakia, 2001); by contrast, desks are considered low-involvement products. (b) These products are relevant to student activities; consequently, the products are easier for students to imagine while avoiding the influence of expert opinions. (c) Prior to this study, we investigated domestic overnight travel packages and solid wood desks that are used by students and are priced similarly in Taiwan at approximately US\$ 300. However, to exclude influences by factors not related to involvement, we use a method developed by Petty, Cacioppo and Schumann (1983) for manipulating involvement.

Additionally, participants are requested to imagine whether or not they require further information about the products. Three different referral reward scenarios are described to the participants as follows. "A friend has introduced a referral rewards program. If you purchase a product or service described previously because of a referral from a friend, (1) you will receive a US\$ 30 voucher; (2) the friend who referred you will receive a US\$ 30 voucher; or (3) both you and your friend will each receive US\$ 15 vouchers." In this study, each participant only see one referral reward scenario and one product or service in the above description. After reading the scenario, participants rate intent to purchase items and manipulation checks, including product involvement.

\subsection{Measures}

All measurement scales used in the present study are measured using a scale ranging from 1 (strongly disagree) to 7 (strongly agree) and are averaged to form a composite index. Purchase intention is measured with three items $(\alpha=0.90)$ used in previous studies by De Carlo (2005) and Zeithaml (1988): consider buying, willingness to buy, and probability of buying the product. Perceived fairness is measured using four items $(\alpha=0.92)$ adopted from Smith, Bolton and Wagner (1999): The outcome I received was fair, I received what I deserved, In resolving the problem, the product provided me with the information I needed and The outcome I received was correct. These items are suggested in the pretest discussions. Product involvement is measured with three items ( $\alpha=0.91$ ) adopted from Lee et al. (2008): How much effort did you put into evaluating the product?, How involved were you in this product?, To what extent were you trying hard to evaluate the product? and How much effort did you put into evaluating the given information?. Perceived reward satisfaction is measured with two items $(r=0.85)$ : I am satisfied with this reward type and I believe that the value of this reward type is sufficient. These items are suggested in the pretest discussions.

\subsection{Results}

Manipulations of reward subjects and product involvement are successful. Participants perceive reward satisfaction similarly across reward subjects $\left(\mathrm{M}_{\text {recipient }}=5.42, \mathrm{M}_{\text {both }}=4.93, \mathrm{M}_{\text {referrer }}=4.88 ; \mathrm{P}<0.01\right)$. The involvement level of the participants in the domestic tourism group is greater than that of those in the desk group $\left(\mathrm{M}_{\text {tourism }}=5.35\right.$ vs. $\left.\mathrm{M}_{\text {desk }}=5.04 ; \mathrm{t}(190)=2.02, \mathrm{P}<0.05\right)$.

We use a two-way analysis of variance (ANOVA) to examine the participants' intent to purchase, employing the reward subject and product involvement as the between-subject factors. The main effects of reward subject ( $\mathrm{F}(2$, $186)=4.65, \mathrm{P}<0.01)$ and interaction $(\mathrm{F}(1,186)=4.88, \mathrm{P}<0.01)$ on intent to purchase is revealed as significant.

The likelihood of receiver intent to purchase is greater in the reward recipient category than it is in both the reward referrer and rewards both categories $\left(\mathrm{M}_{\text {recipient }}=5.43, \mathrm{M}_{\text {referrer }}=5.05, \mathrm{M}_{\mathrm{both}}=4.88\right)$. Contrasts of means reveal a significant difference between the reward recipient and reward referrer conditions $(\mathrm{t}(129)=2.29, \mathrm{P}<$ $0.05)$ and between reward recipient and rewards both conditions $(\mathrm{t}(125)=2.88, \mathrm{P}<0.01)$. The difference between the reward recipient and rewards both conditions is not significant $(\mathrm{t}(124)=0.77, \mathrm{P}=0.45)$.

The main effect of whether a reward exists is significantly moderated by product involvement. As proposed in $\mathrm{H}_{1}$, a significant interaction exists between the reward subject and product involvement $(\mathrm{F}(2,186)=4.88, \mathrm{P}<0.01)$. More specifically, for high-involvement products, offering different reward subjects does affect purchase intention $\left(\mathrm{M}_{\text {recipient }}=5.44, \mathrm{M}_{\text {referrer }}=5.43, \mathrm{M}_{\text {both }}=4.72 ; \mathrm{F}(2,97)=5.53, \mathrm{P}<0.01\right)$. Contrasts of means reveal a significant difference between the reward recipients and rewards both conditions $(\mathrm{P}<0.05)$. The difference between the reward recipient and reward referrer conditions is not significant $(\mathrm{P}=0.95)$, though they are directionally consistent with our prediction. 
Conversely, for low-involvement products, offering different reward subjects does affect purchase intention $\left(\mathrm{M}_{\text {recipient }}=5.42, \mathrm{M}_{\text {both }}=5.06, \mathrm{M}_{\text {referrer }}=4.62 ; \mathrm{F}(2,89)=3.95, \mathrm{P}<0.05\right)$. Contrasts of means reveal a significant difference between the reward recipient and reward referrer conditions $(\mathrm{P}<0.01)$. The difference between the reward recipient and rewards both is $\mathrm{P}=0.21$. The difference between the reward referrer and rewards both conditions is not significant $(\mathrm{P}=0.14)$ (Figure 1). Thus, there is partial support for $\mathrm{H}_{1}$.

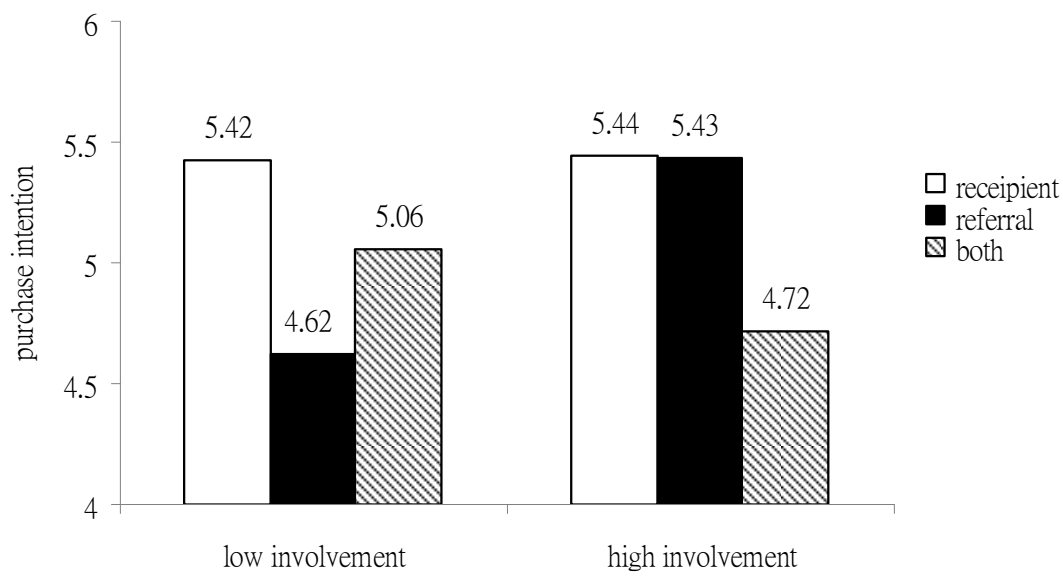

Figure 1. Purchase intention as a function of reward subjects and product involvement

Our primary argument is that the relationship between reward subject and product involvement is mediated by perceived fairness. We test this notion by conducting a four-step mediation analysis (Baron and Kenny 1986) of both dependent variables. In line with hierarchical regression analyses, the interaction between reward subject and product involvement is significant for both intent to purchase $(\beta=-0.18, \mathrm{t}(188)=-2.58, \mathrm{P}<0.05)$ and perceived fairness $(\beta=-0.15, \mathrm{t}(190)=-2.01, \mathrm{P}<0.05)$. Furthermore, perceived fairness predicts purchase intention $(\beta=0.78, \mathrm{t}(189)=13.95, \mathrm{P}<0.01)$. Finally, when purchase intentions are comparatively regressed based on the two independent variables interaction and perceived fairness, perceived fairness remains significant $(\beta=0.76, t(186)=13.35, P<0.01)$, whereas the effect of the interaction is reduced $(\beta=-0.07, t(186)=-1.3, P=$ $0.19)$. A Sobel test indicates that the mediating pathway from the reward subject $\times$ product involvement interaction to purchase intention through perceived fairness is significant $(\mathrm{z}=1.99, \mathrm{P}<0.05$; Sobel, 1982). Thus, the results support the role of conversational perceived fairness as an underlying mechanism for the particular influence of reward subject and product involvement on purchase intention. Thus, $\mathrm{H}_{2}$ is supported.

\subsection{Discussion}

Study 1 shows the importance of considering different subject categories of the reward. From the recipient perspective, reward allocation between existing customers (i.e., referrer) and new customers (i.e., recipient) has an influence on customer intent to purchase, which is primarily determined by the degree of involvement with a product. For high-involvement products, rewarding the recipient or the referrer separately will gain a higher purchase intention than rewarding both. However, there is no significant difference between giving to the recipient or to the referrer. For low-involvement products, giving the reward to the recipient will yield a higher intent to purchase than giving to the referrer.

Study 1 also directly supports the theory of perceived fairness in distributive justice. Customers are typically unwilling to spend time searching for information or considering purchasing decisions prior to purchasing low-involvement products; purchase intentions are only fostered when customers perceive fair rewards. This result coincides with that reported by Choi and Kim (2013), as "customer perceived fairness of justice evaluations" of reward programs influence customer willingness to adopt RRPs.

\section{Study 2: RRP Rewards Types}

\subsection{Perceived Fairness of Reward Type in RRPS}

The methods of using referral rewards are identical to promotional techniques and are commonly employed in marketing communications. Verlegh et al. (2013) suggest further study is needed to examine the effectiveness of non-financial rewards on stimulating referrals. Numerous marketing studies have asserted that consumers have different perceived values for various promotional effects (Chen, Monore, \& Lou, 1998; Hardesty \& Bearden, 
2003). Schmitt et al. (2011) indicate that monetary or rewards in-kind are typical types of rewards. From the recipient perspective, receiving financial rewards (e.g., discount vouchers) following successful referrals can increase the likelihood of an RRP being accepted. Specifically, when enterprises aim to shape customer behavior, compared to high-involvement products, the provision of low-involvement products incurs greater financial and time costs; thus, greater financial incentives are essential (Rothschild \& Gaidis, 1981). Therefore, we assume that the influence of whether financial incentives exist on the likelihood of referral acceptance depends on the level of product involvement. When involvement is low, financial rewards generate greater intent to purchase compared to non-financial rewards.

\subsection{Product Involvement and Perceived Fairness of Reward Type in RRPS}

For high-involvement products, economic exchanges are not an important part of customer requirements. Numerous scholars have contended that for low-involvement products, enterprises must spend more money or provide greater reward incentives to influence customer decisions and behavior (Heslin \& Johnson, 1992; Rothschild \& Gaidis, 1981). That is, the provision of financial rewards provides for higher intent to purchase for low-involvement products, whereas for high-involvement products, no statistical difference is generated according to reward. Thus, when product is high involvement, consumer attitude towards purchasing will be more strongly influenced by the nature of product rather than extraneous factors such as rewards from an RRP. In contrast, when the product is low involvement, consumer decisions should be less dependent on nature of product and therefore more sensitive to external rewards. We propose hypothesis 3 :

$\mathrm{H}_{3}$ : The influence of reward types on recipient response depends on product involvement. Under low involvement, financial reward (compared with a non-financial reward) will result in greater purchase intention. Under high involvement, there is no difference in the purchase intention regarding a reward type.

Equity theory focuses on the motivational and cognitive processes of purchases against rewards. Previous research has found that perceived fairness of distributive justice influences affective reactions to particular outcomes. Providing financial rewards or monetary value increases the perceived fairness that recipients perceive which further affects their satisfaction and behavioral intentions (Mccoll-Kennedy \& Sparks, 2003). Furthermore, moderators such as involvement can be considered relevant. We propose that the fairness of perceived fairness has a mediating effect on intent to purchase, and has a moderating effect with level of involvement. RRPs providing the reward type will influence recipient perceived fairness. The recipient of financial rewards might lead to the highest perceived fairness. Consequently, the following hypothesis is proposed:

$\mathrm{H}_{4}$ : Fairness of distributive justice will mediate the moderation effect of involvement level on the effect of reward type on purchase intentions.

In contrast to Study 1, we select a fitness course package and a set of reference books (encyclopedias) for Study 2 for the following reasons: (a) Books (encyclopedias) have been classified as low-involvement products by previous studies (Chevalier \& Mayzlin, 2006; Gu, Park, \& Konana, 2012), and fitness courses are considered high-involvement products. (b) These products are relevant to the daily activities of students; consequently, they are easier for students to contemplate while avoiding the influence of expert opinion. (c) In addition to increasing the generalizability of this study, this approach facilitates the exclusion of influential factors besides product involvement. This product and service are chosen based on market research conducted prior to empirical testing; the two are consistent with similar products on the market priced at approximately US $\$ 300$.

However, to exclude influences by factors besides involvement, we use the method developed by Petty et al. (1983) for manipulating involvement. The high-involvement domestic fitness course packages are services for market testing and will not be sold within the next month in Taiwan. The low-involvement reference books, which are in development at the time of study and have not been listed on the market, are priced identically to fitness course packages; they will be available for purchase in Taiwan within the next month.

\subsection{Participants, Study Design, and Procedures}

The participants are randomly assigned to one of two (reward: financial vs. non-financial reward) $\times 2$ (product involvement: high vs. low) between-subject experimental design groups. We mainly recruited 267 college student participants from a college in southern Taiwan. Each participant was given extra credit as compensation for participating in this study. The average age of the participants is 21 years; $58.6 \%$ are female.

The recipients in the financial reward manipulation group are given cash vouchers, and those in the non-financial reward manipulation group are given gifts equal in value to the vouchers provided to the financial reward group. The value of these rewards is approximately $10 \%$ of the price of both products (e.g., books and fitness courses) 
used for this study. After reading the scenario page, participants rated items about purchase intention, distributive fairness and manipulation checks that include product involvement and reward type values.

\subsection{Measures}

In addition to measuring purchase intention $(\alpha=0.95)$, perceived fairness $(\alpha=0.93)$, product involvement ( $\alpha=0.83)$ and perceived reward satisfaction $(r=0.84, \mathrm{P}<0.01)$ is identical to that in Study 1 . These items are suggested in the pretest discussion.

\subsection{Results}

First, a series of manipulation check are conducted. Manipulation of the product involvement in the fitness course group is greater than that of the participants in the book group $\left(\mathrm{M}_{\mathrm{fitness}}=5.00 \mathrm{vs}\right.$. $\mathrm{M}_{\text {book }}=4.72 ; \mathrm{t}(265)=$ $2.53, \mathrm{P}<0.01)$. Participant perceived satisfaction similarly across reward type is $\left(\mathrm{M}_{\text {financial }} 5.12=v s . \mathrm{M}_{\text {non-financial }}=\right.$ $4.18, \mathrm{P}<0.01)$. These results indicate that our manipulation is successful.

Second, we conduct a two-way ANOVA to assess participant intent to purchase, using the reward type and product involvement as between-subject factors. The main effects of the reward type $(\mathrm{F}(1,263)=9.43, \mathrm{P}<0.01)$ and product involvement $(\mathrm{F}(1,263)=4.09, \mathrm{P}<0.05)$ are significant. The main effect of reward type is significantly moderated by product involvement. As proposed in H3, reward type and product involvement exhibit a significant interaction $(\mathrm{F}(1,263)=5.54, \mathrm{P}<0.05)$. For high-involvement products, the reward type doesn't have a significant influence on intent to purchase $\left(\mathrm{M}_{\text {financial }}=4.57 \mathrm{vs} . \mathrm{M}_{\text {non-financial }}=4.47 ; \mathrm{t}(128)=0.52, \mathrm{P}\right.$ $=0.60)$. In contrast, for low-involvement products, reward type influences intent to purchase $\left(\mathrm{M}_{\text {financial }}=4.62 \mathrm{vs}\right.$. $\left.\mathrm{M}_{\text {non financial }}=3.82 ; \mathrm{t}(135)=3.74, \mathrm{P}<0.01\right)$; financial rewards generate greater purchase intentions compared to non-financial rewards (Figure 2). Thus, these findings support $\mathrm{H}_{3}$.

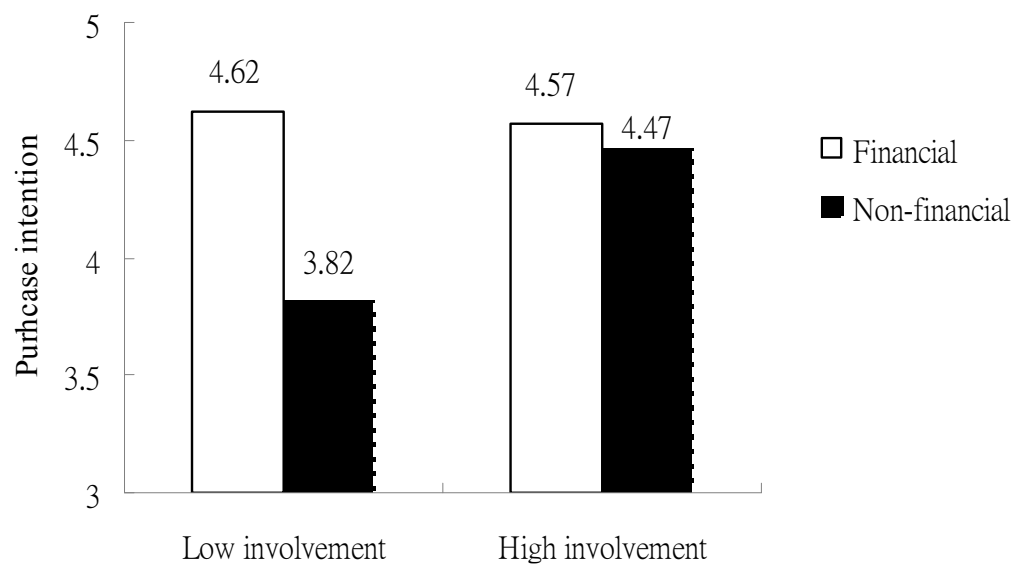

Figure 2. Purchase intention as a function of reward types and product involvement

We test this notion of purchase intention as a function of reward type and product involvement by conducting a four-step mediation analysis (Baron \& Kenny, 1986) of both dependent variables. When purchase intentions are regressed based on reward type, product involvement, and interaction, the interaction term is significant ( $\beta=$ $-0.17, \mathrm{t}(263)=-2.36, \mathrm{P}<0.01)$. When perceived fairness is regressed using the same predictors, the interaction term is also significant $(\beta=-0.14, \mathrm{t}(262)=-2.31, \mathrm{P}<0.01)$. Participant perceived fairness has a significant effect on intent to purchase $(\beta=0.87, \mathrm{t}(263)=16.42, \mathrm{P}<0.01)$. Finally, when purchase intentions are comparatively regressed based on the two independent variables interaction and perceived fairness, perceived fairness remains significant $(\beta=0.85, \mathrm{t}(260)=15.36, \mathrm{P}<0.01)$, whereas interaction declines below the level of significance $(\beta=-0.05, \mathrm{t}(260)=-0.98, \mathrm{P}=0.33)$. The results of a subsequent Sobel test support the mediation effect $\left(\mathrm{z}=2.91, \mathrm{P}<0.01\right.$; Sobel, 1982). Thus, $\mathrm{H}_{4}$ is supported.

\subsection{Discussion}

Study 2 shows that involvement level as a moderating variable affect which reward type will produce greater perceived fairness of distributive justice and intent to purchase. For low-involvement products, customers are more concerned with perceived fairness when the rewards are financial, leading to greater differences in purchase intentions. Conversely, for high-involvement products, the provisions of rewards doesn't increase 
recipient perceived fairness, and financial rewards doesn't increase intent to purchase; this concept is crucial to effectively designing RRPs because RRPs must be designed appropriately to incentivize purchases through WOM referrals. Therefore, customers accept rewards and are persuaded primarily through their perceptions regarding the fairness in distributive justice. When monetary rewards exist, consumers perceive greater outcomes; accordingly, their fairness expectations are more fully satisfied, thus increasing purchasing intentions.

\section{General Discussion and Implications}

Studies 1 and 2 examine the moderating effect of involvement using two high-involvement services (tourism and fitness courses) and two low-involvement products (desks and books) through replicate testing. Not only did this approach facilitate generalizing the research results, it also suggests that the same results can be obtained for recipient perceptions fairness of distributive justice regarding subject categories of reward as well as reward types in RRPs. The results of both Studies 1 and 2 indicate that recipients choose whether or not to accept referrals according to perceptions regarding the fairness in distributive justice, which further affect overall intent to purchase.

This study provides numerous contributions to both WOM marketing and equity theory. First, based on prior studies on WOM referrals in relation to recipients, we find that product involvement is a moderating variable. We test for multiple relationships among high- and low-involvement products and three types of subjects of reward (i.e., referrers, recipients, and both referrers and recipients). Second, past research award for the allocation recipient unknown, this study focuses on receiver responses when the receiver is also aware that both parties are offered incentives. Third, when WOM recipients evaluate product purchases based on whether they perceive that rewards are distributed fairly, intent to purchase for low-involvement products is influenced according to perceived priority of fairness. Finally, we employ differing reward subject categories and financial reward types to increase the understanding of the influence that varying levels of product involvement have on customer purchase intentions.

Our findings indicate some management practice issues; enterprises should practically stimulate these issues to increase recipient purchase intentions. First, our results show that for low-involvement products, enterprises should structure rewards in such a manner that referral recipients perceive fairness in the distribution. In particular, the referrer and the recipient should both be aware of who is rewarded and the amount of the reward in the RRP (Ahrens et al., 2013). Second, when customer purchase intentions are directly correlated to the size of a reward, RRP design for low-involvement products should consider from program initiation the proportion of sales revenue that the rewards will require; this could affect pricing strategies for the product (Barrot, Becker, \& Meyners, 2013). Third, according to our results, high-involvement products are a significant challenge for managers. When purchase intentions don't differ significantly between rewarding the referrer and the recipient, one possible RRP for high-involvement products is increasing the flexibility of consumer choice. For example, RRPs could allow the new customer to choose the subject and type of reward to increase the personal relevance of the RRP. Finally, we also determine the importance of perceived fairness for referral recipients when evaluating purchasing decisions. For marketers, when enterprises employ referrers or certain rewards to investigate customer purchase intentions, firms should understand and survey the perceived fairness expectations and demands of customers who make purchases, conduct a study of whether marketing campaigns satisfy customer needs, and examine how to maximize customer perceived outcomes.

We acknowledge several limitations to the research. First, in this study, we did not take strength into account, but instead simplified the relationship between referrers and recipients as a friend one. The persuasion effect of different relationship strengths is a plausible topic for future research. Second, we only focus on reward subjects and reward types. However, there are likely other relevant factors still, such as reward timing (immediate or delayed), and functionality of reward type (usability or hedonic). These are all worthwhile avenues to explore in future research.

\section{Summary Statement of Contribution}

This study provides numerous contributions to both WOM marketing and equity theory. First, based on prior studies on WOM referrals in relation to recipients, we find that product involvement is a moderating variable. We test for multiple relationships among high- and low-involvement products as well as reward subjects categories: the referrer, the recipient, and both referrer and recipients. Second, while prior studies focus on rewards that are allocated from sources unknown to the recipient, this study focuses on receiver responses when the receiver is also aware of both parties offer incentives. Third, when WOM recipients evaluate product purchases based on whether they perceive that rewards are distributed fairly, their purchase intentions for low-involvement products are prioritize according to perceived fairness. Finally, we vary reward subject 
category and financial reward type to increase the understanding of the influence that varying levels of product involvement have on customer intent to purchase.

\section{References}

Ahrens, J., Coyle, J. R., \& Strahilevitz, M. A. (2013). Electronic word of mouth: the effects of incentives on eReferrals by senders and receivers. European Journal of Marketing, 47(7), 1034-1051. http://dx.doi.org/10.1108/03090561311324192

Baron, R. M., \& Kenny, D. A. (1986). The moderator-mediator variable distinction in social psychological research: conceptual, strategic, and statistical considerations. Journal of the Personality and Social Psychology, 51(6), 1173-1182. http://dx.doi.org/10.1037/0022-3514.51.6.1173

Barrot, D., Becker, J. U., \& Meyners, J. (2013). Impact of service pricing on referral behavior. European Journal of Marketing, 47(7), 1052-1066. http://dx.doi.org/10.1108/03090561311324200

Bowman, D., \& Narayandas, D. (2001). Managing customer-initiated contacts with manufacturers: the impact on share of category requirements and word-of-mouth behavior. Journal of Marketing Research, 38(3), 281-297. http://dx.doi.org/10.1509/jmkr.38.3.281.18863

Celsi, R., \& Olson, J. (1988). The role of involvement in attention and comprehension processes. Journal of Consumer Research, 15(2), 210-224. http://dx.doi.org/10.1086/209158

Chen, S. S., Monroe, K. B., \& Lou, Y. (1998). The effects of framing price promotion messages on consumers' perceptions and purchase intentions. Journal of Retailing, 74(3), 353-372. http://dx.doi.org/10.1016/S0022-4359(99)80100-6

Cheung, M., Luo, C., Sia, C., \& Chen, H. (2009). Credibility of electronic word-of-mouth: informational and normative determinants of on-line consumer recommendations. International Journal of Electronics and Communications, 13(4), 9-38. http://dx.doi.org/10.2753/JEC1086-4415130402

Chevalier, J. A., \& Mayzlin, D. (2006). The effect of word of mouth on sales: online book reviews. Journal of Marketing Research, 43(3), 345-354. http://dx.doi.org/10.1509/jmkr.43.3.345

Choi, S., \& Kim, S. (2013). Effects of a reward program on inducing desirable customer behaviors: the role of purchase purpose, reward type and reward redemption timing. International Journal of Hospitality Management, 32, 237-244. http://dx.doi.org/10.1016/j.jhm.2012.06.003

DeCarlo, T. E. (2005). The effects of sales message and suspicion of ulterior motives on sales person evaluation. Journal of Consumer Psychology, 15(3), 238-249. http://dx.doi.org/10.1207/s15327663jcp1503_9

Dholakia, U. M. (2001). A motivational process model of product involvement and consumer risk perception. European Journal of Marketing, 34(11/12), 1340-1360. http://dx.doi.org/10.1108/EUM0000000006479

Garnefeld, I., Eggert, A., Helm, S. V., \& Tax, S. S. (2013). Growing existing customers' revenue streams through customer referral programs. Journal of Marketing, 77(4), 17-32. http://dx.doi.org/10.1509/jm.11.0423

Gu, B., Park, J., \& Konana, P. (2012). The impact of external word-of-mouth sources on retailer sales of high-involvement products. Information Systems Research, 23(1), 182-196. http://dx.doi.org/10.1287/isre.1100.0343

Hardesty, D. M., Bearden, \& W. O. (2003). Consumer evaluations of different promotion types and price presentations: The moderating role of promotional benefit level. Journal of Retailing, 79(1), 17-25. http://dx.doi.org/10.1016/S0022-4359(03)00004-6

Heslin, R., \& Johnson, B. T. (1992). Prior involvement and incentives to pay attention to information. Psychology \& Marketing, 9(3), 209-219. http://dx.doi.org/10.1002/mar.4220090304

Jin, L., \& Huang, Y. (2014). When giving money does not work: the differential effects of monetary versus in-kind rewards in referral reward programs. International Journal of Research in Marketing, 31(1), 107-116. http://dx.doi.org/10.1016/j.ijresmar.2013.08.005

Kumar, V., Petersen, J. A., \& Leone, R. P. (2010). Driving profitability by encouraging customer referrals: who, when, and how. Journal of Marketing, 74(5), 1-17. http://dx.doi.org/10.1509/jmkg.74.5.1

Laaksonen, P. (1994). Consumer Involvement: concepts and research. London, UK: Routledge.

Lee, J., Park, D., \& Han, I. (2008). The effect of negative online consumer reviews on product attitude: an information processing view. Electronic Commerce Research and Applications, 7(3), 341-352. 
http://dx.doi.org/10.1016/j.elerap.2007.05.004

Mccoll-Kennedy, J. R., \& Sparks, B. A. (2003). Application of fairness theory to service failure and service recovery. Journal of Service Research, 5(3), 251-266. http://dx.doi.org/10.1177/1094670502238918

Oliver, R. L., \& Swan, J. E. (1989). Equity and disconfirmation perceptions as influences on merchant and product satisfaction. Journal of Consumer Research, 16(3), 372-383. http://dx.doi.org/10.1086/209223

Palmer, A., Beggs, R., \& Keown-McMullan, C. (2000). Equity and repurchase intention following service failure. Journal of Service Marketing, 14(6), 513-528. http://dx.doi.org/10.1108/08876040010347624

Petty, R. E., Cacioppo, J. T., \& Schumann, D. (1983). Central and peripheral routes to advertising effectiveness: the moderating role of involvement. Journal of Consumer Research, 10(2), 135-146. http://dx.doi.org/10.1086/208954

Rothschild, M. L., \& Gaidis, W. C. (1981). Behavioral learning theory: its relevance to marketing and promotions. Journal of Marketing, 45(2), 70-78. http://dx.doi.org/10.2307/1251666

Ryu, G., \& Feick, L. (2007). A penny for your thoughts: referral reward programs and referral likelihood. Journal of Marketing, 71(1), 84-94. http://dx.doi.org/10.1509/jmkg.71.1.84

Schmitt, P., Skiera, B., \& Bulte, C. V. (2011). Referral programs and customer value. Journal of Marketing, 75(1), 46-59. http://dx.doi.org/10.1509/jmkg.75.1.46

Smith, A. K., Bolton, R. N., \& Wagner, J. (1999). A model of customer satisfaction with service encounters involving failure and recovery. Journal of Marketing Research, 36(3), 356-372. http://dx.doi.org/10.2307/3152082

Sobel, M. E. (1982). Asymptotic Confidence intervals for indirect effects in structural equations models. Washington, DC: American Sociological Association. http://dx.doi.org/10.2307/270723

Trusov, M., Bucklin, R. E., \& Pauwels, K. (2009). Effects of word-of-mouth versus traditional marketing: findings from an internet social networking site. Journal of Marketing, 73, 90-102. http://dx.doi.org/10.1509/jmkg.73.5.90

Tuk, M. A., Verlegh, P. W. J., Smidts, A., \& Wigboldus, D. H. J. (2009). Sales and sincerity: The role of relational framing in word-of-mouth marketing. Journal of Consumer Psychology, 19(1), 38-47. http://dx.doi.org/10.1016/j.jcps.2008.12.007

Verlegh, P. W., Ryu, G., Tuk, M. A., \& Feick, L. (2013). Receiver responses to rewarded referrals: the motive inferences framework. Journal of the Academy of Marketing Science, 41(6), 669-682. http://dx.doi.org/10.1007/s11747-013-0327-8

Wirtz, J., Orsingher, C., Chew, P., \& Tambyah, S. K. (2013). The role of meta perception on the effectiveness of referral reward programs. Journal of Service Research, 16(1), 82-98. http://dx.doi.org/10.1177/1094670512462138

Xiao, P., Tang, C. S., \& Wirtz, J. (2011). Optimizing referral reward programs under impression management considerations. European Journal of Operational Research, 215(3), 730-739. http://dx.doi.org/10.1016/j.ejor.2011.05.042

Zeithaml, V. A. (1988). Consumer perceptions of price, quality, and value: A means-end model and synthesis of evidence. Journal of Marketing, 52(3), 2-22. http://dx.doi.org/10.2307/1251446

\section{Copyrights}

Copyright for this article is retained by the author(s), with first publication rights granted to the journal.

This is an open-access article distributed under the terms and conditions of the Creative Commons Attribution license (http://creativecommons.org/licenses/by/3.0/). 